\title{
Miranda
}

Revue pluridisciplinaire du monde anglophone /

Multidisciplinary peer-reviewed journal on the English-

speaking world

$8 \mid 2013$

In Umbra Voluptatis : Shades, Shadows, and their

Felicities / Film Adaptations, New Interactions

\section{Jackie Kay, James Procter, and Gemma Robinson, eds, Out of Bounds-British Black and Asian Poets}

\section{Eric Doumerc}

\section{OpenEdition}

\section{Journals}

\section{Electronic version}

URL: http://journals.openedition.org/miranda/3373

DOI: $10.4000 /$ miranda.3373

ISSN: 2108-6559

\section{Publisher}

Université Toulouse - Jean Jaurès

Electronic reference

Eric Doumerc, "Jackie Kay, James Procter, and Gemma Robinson, eds, Out of Bounds-British Black and Asian Poets", Miranda [Online], 8 | 2013, Online since 28 June 2013, connection on 16 February 2021. URL: http://journals.openedition.org/miranda/3373 ; DOI: https://doi.org/10.4000/miranda.3373

This text was automatically generated on 16 February 2021.

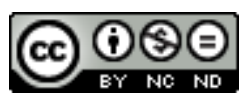

Miranda is licensed under a Creative Commons Attribution-NonCommercial-NoDerivatives 4.0 International License. 


\title{
Jackie Kay, James Procter, and Gemma Robinson, eds, Out of Bounds -British Black and Asian Poets
}

\author{
Eric Doumerc
}

\section{REFERENCES}

Jackie Kay, James Procter, and Gemma Robinson, eds, Out of Bounds-British Black and Asian Poets (Newcastle Upon Tyne: Newcastle University in association with Bloodaxe Books Ltd, 2012), 368 p, ISBN 978-1-85224-929-8

1 Out of Bounds: British Black and Asian Poets is an anthology of poems by writers of African, Caribbean and Asian descent who "have lived and lingered in, who have passed through or been born into" Britain (13), but who are not necessarily "Black British" or "AngloAsian" in the sense of having been born and brought up in Britain. What brings together the poets gathered in this anthology is that they have all, at one point in their lives, lived in Britain. So the subtitle is slightly misleading as the reader might be led to expect a "traditional" anthology of Black and Asian writing. The three anthologists have tried to break new ground by inviting the reader to "travel from north to south" (13) and to consider their anthology as "an alternative A-Z of poetic Britain" (26). The reader is invited to "stroll through the distinct localities" (13) that all these poets evoke in their writings and to see Britain through their eyes. Remapping, dual or multiple loyalties, the pull of home and landscape, attachment to place and what home may mean are important concepts which lie behind this project.

2 The anthology is divided into geographical sections (Scotland, the North, Wales, the Midlands, and the South) which correspond to a poetic journey from "the Shetland Isles" to the "Isle of Wight" (13). The advantage of such a division is that the reader really feels as if he or she were travelling on an Intercity train from Glasgow to London, recognizing many places and landmarks. The geographical sections also work as mini- 
anthologies of regional poetry by Black and Asian poets and can stand on their own. They also allow the reader to experience multiple perspectives on a single area or town. The downside of such an approach is that many themes recur throughout the sections or from one section to another, and this can leave the reader with the impression that the same themes recur again and again.

The anthology avoids some of the major pitfalls associated with anthologies of Black and Asian writing. One of these pitfalls is a concentration on themes like alienation, dislocation, racism and homesickness. Although these themes can indeed be found in the present anthology, other themes emerge like the attachment to Britain as home, the translation of landscapes across cultures and the theme of dual loyalties. The anthology also breaks new ground by offering a regional perpective on the Black and Asian presence, whereas previous anthologies (for instance James Berry, ed. News for Babylon: The Chatto Book of West Indian-British Poetry [London : Chatto and Windus, 1984] or Lemm Sissay, ed. The Fire People: A Collection of Contemporary Black British Poets [Edinburgh: Canongate Books Ltd 1998]) were associated with an urban context.

Lastly, language or language as the expression of a regional or local identity emerges as an important theme in this collection. Although the themes of alienation and unbelonging do crop up in many pieces, this anthology offers new perspectives on "the rich and manifold attachments to place" (13) which characterize British Black and Asian poetry. So alongside Kwame Dawes' "Bristol", Wole Soyinka's "Telephone Conversation" and Linton Kwesi Johnson's "Di Great Insohreckshan", we find pieces like Grace Nichols' "Angel of the North", which celebrate the North's unflinching spirit, and Fred D'Aguiar's "Home" which makes the simple point that England is now the poet's "Home". Monica Alvi's "Rural Scene", about the incongruity of an Asian walking down a village street in Norfolk is counterbalanced by Merle Collins' "For the Lumb Bank Group, December 1991" with its memorable conclusion: "warmth might just/ sometimes/be found in misty cold" (108).

In many pieces, a dialogue of cultures or landscapes is staged by the poets, with Trinidad's hummingbird being associated with Yorkshire's blackbird in John Lyions' "Drinking Up the Drizzle" (118). The poems by Sheree Mack and Nabila Jameel often stage dual or multiple loyalties (for instance Nabila Jameel's "A Book Closer to Home", 124)). John Lyons' "Weather Vane" falls into two sections, one about the Calder valley in Yorkshire and the other about Trinidad, and it looks at these two distinct areas through the poetry of Ted Hughes and Derek Walcott.

6 The present anthology also breaks new ground by offering a regional perspective on the Black and Asian presence in Britain. Indeed, the North of England is powerfully evoked in pieces like "Angel of the North" by Grace Nichols, John Siddique's "Industrial Landscape" and Seni Seneviratne's "Yorkshire Childhood" while the commanding presence of nature in Scotland and Wales is an important theme in Rizwan Akhtar's "Aberdonian Winter" (33) and in Moniza Alvi's "Spring on the Hillside" (161) respectively. The poems about the Midlands range from evocations of the region's industrial heritage (Sue Brown's "Birmingham", 189) to celebrations of its vibrant muticultural nature (Benjamin Zephaniah's "The Big Bang", 194). But the dub poet Moqapi Selassie's “Tellin de Stori” (190) and Martin Glynn's "Highfields Style” (183) remind the reader of the tensions that often characterize life in Britain's inner cities.

7 Moreover, language as the expression of a regional or local identity emerges as a powerful theme. For many of these poets finding a space in Britain or finding a place 
was negotiated through the process of learning a new language. Thus Seni Seneviratne's "Frame Yourself" (89) takes as its starting point a Yorkshire expression which means "sort yourself out" to make a point about tuning your ears to a new environment. Jean Binta Breeze's "Mi Duck" takes its title from the West Midlands phrase meaning "mi love" and makes it clear that the poet feels quite at home in Leicester in spite of the forbidding weather :

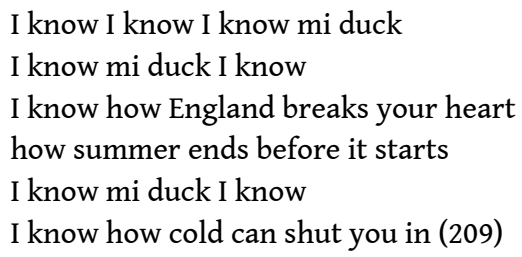

Roger Robinson's switches back and forth bewteen Scots and Trinidadian English in his "Conversion" and the Scots phrase "Lukeit theis evrybuddy" becomes "All of alluyh, check dis out nuh" in Trinidadian dialect (39). Raman Mundair's "Name Journeys" insists on the difficulty of learning to speak with a Manchester accent (131).

On the whole, Out of Bounds offers a comprehensive poetic remapping of Britain and takes the reader on a journey through multiple identities and multiple landscapes. It is an innovative and forward-looking anthology which should delight all poetry lovers.

\section{INDEX}

Mots-clés: anglo-antillais, asiatique, caraïbe, carte, identités multiples, indo-pakistanais, poésie, voyage

Keywords: Black British, Caribbean, journey, map, multiple identities, poetry

\section{AUTHORS}

\section{ERIC DOUMERC}

Université de Toulouse 2-Le Mirail

Maître de Conférences

doumerceric@neuf.fr 